\title{
PRESUMPTIVE REOVIRUS INFECTION IN BROILER BREEDERS
}

\author{
Moreira, F.A., M.L. Pinto, L. Cardoso and A.C. Coelho \\ Department of Veterinary Sciences, School of Agrarian and Veterinary Sciences, \\ University of Trás-os-Montes e Alto Douro (UTAD), \\ Veterinary and Animal Science Center (CECAV), Vila Real, Portugal
}

Received 2014-01-13; Revised 2014-01-16; Accepted 2014-02-03

\begin{abstract}
Tenosynovitis is one of the pathological manifestations of avian reovirus infection and are of economic importance, special in one of the most important stages of the poultry industry, i.e., broiler breeders. In late May 2012, an outbreak of unilateral lameness occurred in a broiler breeder flock $(15,000$ birds divided by two houses) of a multi-age farm, with a total of four broiler breeder flocks $(65,000$ birds in total). Birds aged from 20 to 30 weeks presented joint lesions. Morbidity ranged between 5 and $10 \%$. Routine postmortem examination of 30 birds revealed a range of visible joint lesions, typically unilateral in distribution. After postmortem examination, samples of tendons, heart and liver were collected for histopathology, bacteriological culture and polymerase chain reaction analysis. Microscopic examination of the tendons revealed changes consistent with a reovirus infection and, to the authors' knowledge, these are the first reported cases of viral arthritis in broiler breeders in Portugal.
\end{abstract}

Keywords: Broiler Breeders, Poultry, Reovirus, Tendon Rupture

\section{INTRODUCTION}

Viral arthritis/tenosynovitis in poultry is one of the pathological manifestations of avian reovirus (Reoviridae) infection. These viruses can act alone as a pathogenic agent or in combination with one or more other agents, such as Mycoplasma synoviae or Staphylococcus spp., leading to varied clinical pictures of arthritis/tenosynovitis (Jones, 2013). Avian reoviruses are of economic importance to the poultry industry. They can infect birds without any signs of disease, but they are also associated with a variety of manifestations including viral arthritis/tenosynovitis, enteric disease and malabsorption syndrome (Roussan et al., 2012).

\section{CASE DESCRIPTION}

In late May 2012, an outbreak of unilateral lameness occurred on a broiler breeder flock $(15,000$ birds divided by two houses) of a multi-age farm, with a total of four broiler breeder flocks $(65,000$ birds in total). Birds aged from 20 to 30 weeks of age presented joint lesions. Morbidity ranged between 5 and $-10 \%$. Routine postmortem examination of 30 birds revealed a range of visible joint lesions, typically unilateral in distribution. Eighty percent of the examined birds presented unilateral arthritis and tenosynovitis affecting the hock joint, $30 \%$ of then with rupture of the gastrocnemius tendon and 5\% exhibiting femoral osteomyelitis. The rest of the examined birds didn't reveal any articular or tendon lesion.

A standard breeder vaccination program was applied, including vaccination with reovirus, 1733 and 2408 strains (Nobilis ${ }^{\circledR}$ Reo inac., MSD).

Samples of tendons, heart and liver were collected for histopathology, bacteriological culture and Polymerase Chain Reaction (PCR) analysis.

\section{Corresponding Author: Moreira, F.A., Department of Veterinary Sciences, School of Agrarian and Veterinary Sciences, University of Trás-os-Montes e Alto Douro (UTAD), Veterinary and Animal Science Center (CECAV), Vila Real, Portugal Tel.: +351 912875440; Fax: +351 244825262}




\subsection{Histopathology}

For histopathologic analysis, field samples of tendons were randomly collected from hens within $8 \mathrm{~h}$ after natural dead, fixed in $10 \%$ neutral buffered formalin and embedded in paraffin according to standard laboratory procedures. Field samples were submitted to a commercial laboratory (PDRC, Athens, USA).

Liver and spleen samples were mixed in sterile plastic bags with sterile physiological saline solution $(0.85 \% \mathrm{NaCl})$ for $2 \mathrm{~min}$ and inoculated and incubated at $37^{\circ} \mathrm{C}$ for $24-48 \mathrm{~h}$ using traditional method which include culture characteristic on selective media, Gram-staining and biochemical reactions (Holt et al., 1994).

\subsection{PCR}

For PCR analysis, field samples were randomly collected from hens within $8 \mathrm{~h}$ after natural dead and submitted to a commercial laboratory (Controlvet, Tondela, Portugal). Samples of tendons (six per house) were prepared for $M$. synoviae PCR, as described by Ramirez et al. (2006). Briefly, $900 \mathrm{~mL}$ of initial cell suspensions were centrifuged $\left(12,000 \times \mathrm{g}, 4^{\circ} \mathrm{C}, 20 \mathrm{~min}\right)$ and the pellets were washed once in $500 \mu \mathrm{L}$ of Phosphate Buffer Saline (PBS) and resuspended in 20 $\mu \mathrm{L}$ of PBS. Samples were heated at $95^{\circ} \mathrm{C}$ for $2 \mathrm{~min}$. The DNA of the M. synoviae was quantified with a fluorometer (DyNA Quant ${ }^{\mathrm{TM}}$ 200, Hoefer, Pharmacia Biotech Inc.) following the manufacturer's instructions. Primer (Ms2FF 5'-TAA AAG CGG TTG TGT ATC GC-3') was used with a reverse primer (23SR 5'-CGC AGG TTT GCA CGT CCT TCA TCG-3') targeting the 5 ' end of the $23 \mathrm{~S}$ rRNA gene. Reaction mixtures contained 2.5 U of Taq DNA polymerase (AB Gene), $0.2 \mu \mathrm{M}$ of Ms $2 \mathrm{FF}$ primer, $1 \mathrm{x}$ reaction buffer, $1.75 \mathrm{mM}$ $\mathrm{MgCl}_{2}, 0.2 \mathrm{mM}$ dNTPs and water to a volume of 50 $\mu \mathrm{L}$. One microliter of the template was added. Amplification was achieved with a first step at $80^{\circ} \mathrm{C}$ for $30 \mathrm{~s}$, five denaturation cycles at $94^{\circ} \mathrm{C}$ for $15 \mathrm{~s}$, renaturation at $55^{\circ} \mathrm{C}$ for $30 \mathrm{~s}$ and elongation at $72^{\circ} \mathrm{C}$ for $1 \mathrm{~min}$, followed by 30 cycles as previously described but with an extension of $2 \mathrm{~s}$ per cycle in the elongation step. A $5 \mu \mathrm{L}$ amount of each amplified product was separated by electrophoresis on a $1.5 \%$ agarose gel. Gels were stained with ethidium bromide $\left(3 \mu \mathrm{g} \mathrm{mL}^{-1}\right)$ and observed with ultraviolet light.

Samples of tendons, heart and liver (six per house) were prepared for reovirus RT-PCR reaction and agarose gel electrophoresis as described by Bruhn et al. (2005). Briefly, the RT-PCR reactions were performed with the One Step RT-PCR Kit (Qiagen, Switzerland) using a standard $50 \mu \mathrm{L}$ reaction mixture contained $10 \mu \mathrm{L} 5 \mathrm{x}$ OneStep RT-PCR buffer, $2 \mu \mathrm{L}$ dNTP mix (containing 10 $\mathrm{mM}$ of each deoxynucleoside triphosphate), $0,8 \mu \mathrm{M}$ $(2 \mu \mathrm{L})$ of each primer (ARV_S2_P4 (CCC ATG GCA ACG ATT TC), ARV_S2_P5 (TTC GGC CAC GTC TCA AC), ARV_S4_P4 (GTC CGT GTT GGA GTT TC) and ARV_S4_P5 (ACA AAG CCA GCC AT(G/A) AT)) $\left(20 \mu \mathrm{mol} \mathrm{L}{ }^{-1}\right), 2 \mu \mathrm{L}$ of One Step RT-PCR Enzyme mix, $0,25 \mu \mathrm{L}$ RNAse inhibitor (40 U $\mu \mathrm{L}^{-1}$, Promega). Two microlitres of the extracted RNA or RNA/DMSO mix were used in the RT-PCR reaction. In the reagent control, templates were replaced by RNAse free-water. Target DNA was amplified in a $0,5 \mathrm{~mL}$ thin walled tube using a thermocycler equipped with a heat lid (Hybaid OmnE, MWG-Biotech) or with the Mastercycler@ gradient (Eppendorf Inc.). The temperature profile consist of an initial $50^{\circ} \mathrm{C}$ for $30 \mathrm{~min}$ for reverse transcription, RT-PCR activation step of $95^{\circ} \mathrm{C}$ for $15 \mathrm{~min}$ followed by 35 cycles for $30 \mathrm{~s}$ at $94^{\circ} \mathrm{C}$ for denaturation, $30 \mathrm{~s}$ at $54^{\circ} \mathrm{C}$ for annealing, $1 \mathrm{~min}$ at $72^{\circ} \mathrm{C}$ for elongation and a final extension step of $10 \mathrm{~min}$ at $72^{\circ} \mathrm{C}$. A $100 \mathrm{bp}$ double-stranded DNA ladder (Invitrogen Life Technologies, USA) served as molecular DNA size marker. Ten microlitres of RT-PCR products were analysed by electrophoresis on $2 \%$ agarose gel (Sigma Chemicals, Switzerland) containing $0,3 \mu \mathrm{g} \mathrm{mL}^{-1}$ ethidium bromide. The gels were run at $120 \mathrm{~V}$ for $1,2 \mathrm{~h}$ using 1 x TBE buffer (44,6 mM Tris, 44,5 mM Boric acid, $1 \mathrm{mM}$ EDTA) and examined with ultraviolet light.

\section{RESULTS}

Mycoplasma synoviae and Avian reovirus were not detected by PCR and the bacteriological cultures were negative. However, histopathological findings were compatible with avian reovirus. Microscopic examination of the tendons revealed one section with mild numbers of lymphocytes diffusely underneath the synovial lining of the tendons. Another section has hyperplastic synovial cells lining the tendon sheath. Mild diffuse lymphocytic tenosynovitis was observed.

Vaccination of the flock with reovirus, 1733 and 2408 strains (Nobilis ${ }^{\circledR}$ Reo inac., MSD) had apparently been ineffective.

\section{DISCUSSION}

As Hill et al. (1989) indicate, histological differences are seen between reovirus and other aetiological agents but final diagnosis is not definitive. More studies shows frequent suspicious of reovirus infections in broiler 
breeders, however the final diagnose is not always achieved (Crespo and Shivaprasad, 2011; Day, 2009).

This type of birds stays long periods in the rearing and production sites. This means that they are susceptible to several agents that interfere with the defense system and predispose to infection (Jones, 2013). The construction of multi-age farms (farms with birds of different ages) seen in the newest facilities, pose a significant epidemiological risk (Gharahveysi et al., 2012). Although very strict hygiene rules are being implemented, poultry farms built in the latest years are designed based on an economical perspective. Very rarely is disease prevention a primary consideration. The consequence is that farms have grown in size and density and an ideal environment was created for agents as reovirus to thrive (Gharahveysi et al., 2012).

There are currently very few available reovirus vaccines in Portugal and appear to be ineffective for the detected problem. Few similar cases are reported in Europe although, to our knowledge, it seems to be underdiagnosed. Unfortunately this fact leaves to poor commercial interest in vaccines and investigation.

\section{CONCLUSION}

Avian reovirus has economic impact in the poultry industry. There are many suspicious cases but diagnosis is difficult. This outbreak was unusual since clinical reovirus infections occur mostly in early weeks of age. Histopathology could be useful but is not a method of definitive diagnosis. More research is required to understand the underlying basis of pathogenicity, improve the diagnose techniques and develop new control strategies.

It is necessary to determine new and more effective strategies to reduce losses due to these agents (Jones, 2013). Economic losses reports increase every day, including leg problems.

\section{REFERENCES}

Bruhn, S., L. Bruckner and H.P. Ottiger, 2005. Application of RT-PCR for the detection of avian reovirus contamination in avian viral vaccines. J. Virol. Meth., 123: 179-186. DOI: 10.1016/j.jviromet.2004.09.019
Crespo, R. and H.L. Shivaprasad, 2011. Rupture of gastrocnemius tendon in broiler breeder hens. Avian Dis., 55: 495-498. PMID: 22017054

Day, J.M., 2009. The diversity of the orthoreoviruses: Molecular taxonomy and phylogenetic divides. Infect. Genet. Evolut., 9: 390-400. DOI: 10.1016/j.meegid.2009.01.011.

Gharahveysi, S., S.M.F. Niaki and M. Irani, 2012. The effect of broiler breeder ages on the qualitative and quantitive properties of the egg. Am. J. Anim. Vet. Sci., 7: 136-140. DOI: 10.3844/ajavsp.2012.136.140

Hill, J.E., G.N. Rowland, J.R. Glisson and P. Villegas, 1989. Comparative microscopic lesions in reoviral and staphylococcal tenosynovitis. Avian Dis., 33: 401-410. PMID: 2549934.

Holt, J.G., N.R. Krieg, P.H. Sneath, J.T. Safety and S.T. Williams, 1994. Bergey's Manual of Determinative Bacteriology. 9th Edn., David Hendricks Bergey, Baltimore, USA., ISBN-10: 0683006037, pp: 787.

Jones, R.C., 2013. Reovirus Infections. In: Diseases of Poultry, Swayne D.E., J.R. Glisson, L.R. McDougald et al. (Eds.), Iowa, USA., ISBN-13: 9780470958995. pp: 352-361.

Ramirez, A.S., J.N. Clive, P.P. Hammond and J.M. Bradbury, 2006. Development and evaluation of a diagnostic PCR for Mycoplasma synoviae using primers located in the intergenic spacer region and the 23 rRNA gene. Vet. Microbiol., 118: 76-82. DOI: 10.1016/j.vetmic.2006.06.021

Roussan, D.A., I.A. Shaheen, G.Y. Khawaldeh, W.S. Totanji and R.H. Al-Rifai, 2012. Simultaneous detection of astrovirus, rotavirus, reovirus and adenovirus type I in broiler chicken flocks. Polish J. Vet. Sci., 15: 337-344. PMID: 22844713 